\title{
Business Process Reengineering in Government Agencies: Lessons from an Experience in Mexico
}

\author{
Jaime Torres Fragoso \\ Department of Public Administration, Universidad del Istmo, Ixtepec, Mexico \\ Email: jaimetorres@bianni.unistmo.edu.mx
}

Received 18 April 2015; accepted 22 June 2015; published 26 June 2015

Copyright @ 2015 by author and Scientific Research Publishing Inc.

This work is licensed under the Creative Commons Attribution International License (CC BY). http://creativecommons.org/licenses/by/4.0/

\section{(c) (i) Open Access}

\begin{abstract}
This paper is based on the findings from two research projects in the Mexican port subsector and shows evidence that business process reengineering is a viable tool for government reform in Latin America. The paper opens with a brief description of New Public Management (NPM), a model used in recent efforts for state reform in the region of Latin America. The modernization of Mexican ports is based on the NPM paradigm. The following section includes a definition of business process reengineering, its methodology and relevance for the public sector. Subsequently, the development of the projects is outlined, including their main objectives and justification, the methodology used, the participating employees, and the results achieved. The findings of these projects are both significant and thought-provoking. The paper concludes with a series of recommendations for the implementation of business process reengineering in the public sector.
\end{abstract}

\section{Keywords}

Reform, Government, Reengineering, Efficiency, Public Service

\section{Introduction}

In recent years, Western governments, especially those who are part of the Organization for Economic Co-operation and Development (OECD), have implemented actions to change the way they run service production processes and how these administrations relate to citizens. These efforts tend to change the paradigms on which governance is based. At first, these changes came from the experience within the bureaucratic apparatuses of various governments in developed countries. Then, scholars analysed and conceptualized these changes and built a model known as New Public Management (NPM). The main components of this model are known as the 
"5Rs": restructuration, process reengineering, reinvention, realignment and reconceptualization.

Latin American organizations have also implemented similar changes. Reforms have taken place at various levels of government (national, regional and local). These reforms aim to reverse well known deficiencies, especially the quality of public services, their effectiveness and management efficiency.

The results in Latin America cannot be compared to the results obtained in English-speaking countries such as Australia, the United States, England and New Zealand. Indeed these pioneer countries, in transforming their governmental structures under the paradigm of NPM, have different resources, problems and contexts. Also, in our region the products of these actions have been diverse and far from fully meeting the expectations of citizens. From the NPM perspective, the citizen is seen as a client who is increasingly informed and demanding. However, in our subcontinent there are cases of transformations, inspired by this management model, which can be considered successful. For instance, in the port subsector in Mexico, where normative, structural and administrative transformations took place in the whole system, the results were positive (Torres, 2013, [1]).

Given this situation, the only alternative is to intensify efforts to ensure that government institutions, where citizens are seen as customers, effectively manage public resources and provide quality service. To meet this challenge the best available management tools must be used, regardless of their origin. An ethnocentric vision is not convenient for our public administration. Obviously, any theory or tool from a distant geographical, economical and social context will need fundamental adjustments to make it functional in our particular managerial reality.

This work shows that business process reengineering, when used not as a trendy or ostentatious resource but as a means for better public institution management, is a viable instrument for state improvement in Latin America and for meeting the demands of citizens.

\section{Conceptual Framework}

\subsection{The Meaning of Business Process Reengineering}

As many administrative techniques, Business Process Reengineering (BPR) originated in the United States. Since the 1990s, BPR has been one of the most frequently used tools in organizations, such as private companies or government agencies, to improve processes in the production of goods or services. According to Michael Hammer and James Champy who coined the term in a book that revolutionized the business world, reengineering is "the fundamental rethink and radical redesign of business processes to generate dramatic improvements in critical performance measures-such as cost, quality, service and speed" (Hammer and Champy, 1993: p. 32, [2]). Whereas for Manganelli and Klein (1995: p. 8) [3], BPR is the rapid and radical redesign of strategic processes to add value. It is also the redesign of systems, policies and organizational structures that support the processes to optimize workflows and productivity of an organization. According to these authors, strategic processes are the most relevant. They are essential for the fulfillment of the objectives, goals, positioning and strategy of any organization. On the other hand, the processes for added value are also indispensable to meet the requirements and needs of the clients willing to pay.

\subsection{Suggested Methods for the BPR Projects}

The topic of reengineering processes has been controversial to some extent. Several scholars credit themselves as being creators of a particular new method. Some guarantee success in implementing reengineering projects when their precepts are followed. Actually, there are no truly innovative methods. The improvement of processes, whether gradual or radical, has been practiced for decades in public and private bureaucracies by enthusiastic supporters of Taylor and Ford and their School of Scientific Management from early last century.

In this regard, prestigious organizations such as the Institute of Industrial Engineers (IIE) (1995: p. 9) [4] formulate that there is no single or prevailing method around BPR and there are no completely new techniques that could be expected. However, there is a new and bolder way of combining known techniques together. Time and motion studies, flowcharts, rolling of production lines, automation, reorganization, downsizing and quality management are some of these techniques. That combination of techniques is precisely what distinguishes BPR from other techniques. BPR attempts to bring radical rather than incremental changes and focuses on continuous improvement, consistent with the vertiginous changes that contemporary civilization experiences in social, eco- 
nomic, industrial and governmental areas. Regardless of the debate on the novelty of its components, the crucial point is to recognize the importance of the consistent use of management methods to ensure success in projects of this type. In addition, the formation of a team sufficiently familiar with BPR work is necessary. Table 1 summarizes the methods proposed by some of the most acknowledged authors in this field.

The methods proposed, both by IIE and by Manganelli and Klein, are markedly holistic. Indeed, they raise a broader view of the large system that constitutes an organization. They also have a fresh vision of the way to achieve the transformation of vital processes through the application of administrative processes. Whereas, Harbour suggests a technique that concentrates on the analysis and improvement of strategic processes, i.e., the best way to transform the inputs into outputs.

Regarding the work team of participants, BPR supporters point out that the participation of a senior executive (Leader) is needed at first. The leader establishes the goals and acts as the sponsor and promoter of the project. A Guidance Committee whose members are managers or directors of departments needs to be established. They support the Leader and are responsible for solving significant problems and forming project teams with the appropriate people. The participation of a consultant (the expert in Reengineering), who at first can be an external agent and then be trained as an internal specialist, is crucial for the project coordination and to instruct staff in BPR techniques. Finally and most importantly, a Process Design Team will be formed by selecting the brightest staff from each department. This team will actually apply the BPR organizational subsystems under the supervision and support of the other groups (McDonald, 1996: p. 31, [6]).

\subsection{BPR in the Public Sector}

There was a strong current of PR application in the field of business and private manufacturing plants ${ }^{1}$, almost simultaneously with the emergence of ideas around PR. That flow of actions soon reached governments, first in the United States, where PR initiatives have taken place with very contrasting results. Caudle (1994: p. 149) ${ }^{2}$ [7] published the following:

\section{Table 1. BPR method.}

\begin{tabular}{|c|c|}
\hline Author & Components \\
\hline $\begin{array}{l}\text { Institute of Industrial } \\
\text { Engineers (IIE) }\end{array}$ & $\begin{array}{l}\text { 1. Start of the project } \\
\text { 2. Comprehension of the process. } \\
\text { 3. New process design. } \\
\text { 4. Business Transition. } \\
\text { 5. Administration of the change }\end{array}$ \\
\hline Manganelli and Klein & $\begin{array}{l}\text { 1. Preparation. Consensus on objectives and goals. } \\
\text { 2. Identification. Development of a client oriented business model } \\
\text { and identification of the added value strategic processes. } \\
\text { 3. Vision. Seeks for decisive improvement process strategies. } \\
\text { 4. Solution. Technical and human resource design to implement the improvements. } \\
\text { 5. Transformation. To implement the improvements and the new processes. }\end{array}$ \\
\hline Jerry L. Harbour & $\begin{array}{l}\text { 1. To define the limits of the process. } \\
\text { 2. To observe the steps of the process. } \\
\text { 3. To gather relevant data to the process. } \\
\text { 4. To analyse the data. } \\
\text { 5. To identify the areas to improve. } \\
\text { 6. To develop improvements. } \\
\text { 7. To set up and monitor the improvements. }\end{array}$ \\
\hline
\end{tabular}

Source: IIE (1995), Manganelli and Klein (1995), Harbour (1995) [5].

\footnotetext{
${ }^{1}$ According to a study done in 1994, 95\% of medium-sized US companies claimed that at least part of their organization had experienced PR and $30 \%$ of them said they had applied RP to their entire company in the last three years (IIE, 1995: p. XI).

${ }^{2}$ In this document, the reader will find a wide range of interesting cases on the implementation of PR initiatives in the US public sector and elsewhere.
} 
Reinventing government relies heavily on efforts to revise government service and product delivery-the process key to how government does its work. Business process reengineering, or simply reengineering, is the latest management initiative specifically targeted at radically changing these processes for major gains in service and product delivery. Reengineering is best known in the private sector (Carr and others, 1992; Davenport, 1993; Hammer and Champy, 1993; Harrington, 1991) and is now infiltrating government. Many government organizations are scrambling to understand and initiate reengineering for their own service and product delivery business processes (Corbin, 1993; Moore, 1993; National Association of State Information Resource Executives, 1993).

Since that time, government agencies and academic institutions in Latin America have made serious efforts through courses, workshops, conferences, seminars and diplomas, to spread this technique within their state agencies. It is worth mentioning the work of the Centro Latino Americano de Administración para el Desarrollo (CLAD), which is the most important organization of the subcontinent in promoting the modernization of the state, government and public administration in the region. The CLAD website presents more than 30 papers, courses and examples related to business process reengineering in Latin America ${ }^{3}$. However, some examples in countries such as the United States and Korea are also mentioned.

The Lisbon Declaration confirms the relevance (or what should be the relevance) of the ideas proposed by business process reengineering for our governments. The ministers and delegates of Argentina, Bolivia, Brazil, Chile, Colombia, Costa Rica, Cuba, El Salvador, Spain, Guatemala, Mexico, Nicaragua, Panama, Paraguay, Portugal, the Dominican Republic, Uruguay and Venezuela signed the Declaration at the first Latin American Conference on Public Administration and State Reform that was held on July $27^{\text {th }}$ and $28^{\text {th }} 1998$ in Lisbon, Portugal. As its name suggests, this document proposes a set of guidelines for the reform of the role and management of the state in the region. These reforms will be made through the incorporation of principles for quality, effectiveness and efficiency, in balance with equity. Specifically, the tenth proposal to improve our governance expresses:

Significant investment in information technology and in business process reengineering is necessary to make sure the technological revolution is done following a redesign of processes and organizations in accordance with the innovations (CLAD, 1998, [8])

The Santo Domingo Declaration, signed by the same participating countries except for El Salvador, Nicaragua and Uruguay, is a new product that is complementary to the Fourth Latin American Conference of Public Administration and State Reform, held between June 27th and 28th, 2002 in the Dominican Republic. This document, just as the Lisbon document does, outlines a set of strategies for the professionalization of public service in the implementation of New Public Management in Latin America. In this regard, the seventeenth line of action states the policies and reforms to be developed to achieve this purpose:

Standards, processes and administrative processing reengineering need free information channels and decision making flow, elimination of redundancies and improvement of efficiency, effectiveness and social relevance of the management to remove obstacles and unnecessary steps in the daily management. (CLAD, 2002, [9]).

\section{BPR Initiatives in Port Administration}

\subsection{The New Context of Mexican Ports and the Project Objectives}

In Mexico, since the early nineties a series of measures intended to improve the way the government operate the

\footnotetext{
${ }^{3}$ Among the documents, the Lisbon Declaration (1998) and the Santo Domingo Declaration (2002), which will be addressed later, are noticeable. In the second group, Reingeniería de Procesos en el Servicio Público, a postgraduate course offered by the INAP, Dominican Republic "stands out. Among all experiences presented at international congresses of CLAD, these are particularly relevant: 1). Reingeniería de servicios municipales: el caso de las licencias en el municipio de Zapopan, México; 2). Reingeniería y desconcentración del proceso de adquisiciones del gobierno estatal: el caso del estado de Jalisco. Both of them belong to the panel "Modernización, reingeniería y certificación de procesos de la administración pública: casos estatales y municipales en México (México, 1999)”; 3). Enfoque metodológico utilizado para la reingeniería de los procesos administrativos en el gobierno de la provincia de Salta, Argentina, which is part of the panel Un enfoque integral exitoso aplicado a la modernización de la gestión gubernamental de la provincia de Salta, Argentina (Argentina, 2001); 4). Reingeniería de procesos: herramienta que consolida la modernización del Estado, a case that was reported to the General Comptroller of the Republic of Chile and part of the panel Modelo de integración institucional: una exigencia para la modernización de la gestión pública (Portugal, 2002); 5). Reingeniería de sistemas: gobierno electrónico en la administración descentralizada, that was applied to the Administración Federal de Ingresos Públicos (AFIP) of Argentina and that belongs to the panel ¿Cómo mejorar la gestión pública? (Argentina, 2008 (CLAD, 2011, [10]).
} 
port subsystem has been implemented. The possible involvement of private capital both in cargo loading and unloading terminals (eliminating the state monopoly prevailing before the reform) and in the port administration are the most prominent measures. In addition, each port is meant to be totally autonomous, to manage the determination of their fees according to the market economy and to adopt a business management approach. In this important project, the main objectives are full customer satisfaction, efficient operations, an administration with defined objectives, service delivery with quality parameters in terms of time, cost, safety and ecology, a structuring around processes rather than hierarchies and functions, and profit economic rate of return.

To meet these objectives, the federal government planned the emergence of organizations responsible for compliance: the Administraciones Portuarias Integrales (APIs). These organizations run the most important port facilities in Mexico. They are both operationally and financially autonomous, according to the philosophy described above ${ }^{4}$.

The idea of developing BPR projects in ports in Mexico emerged in this context. The projects are an attempt for the establishment of a new management style in this subsector. Initially, an invitation was extended to the directors of the APIs asking them to revise the way strategic processes were run within their organizations, so areas of opportunity for improvement in terms of cost revision, time and security could be identified.

The Guaymas and Puerto Vallarta APIs responded positively. These institutions formally implemented BPR initiatives. Even if these institutions belong to the port system, their missions are entirely different. Guaymas, for instance, is a loading port (mostly agricultural bulk and minerals) that has a regional impact. It is seventh place in the country in importance of cargo operations and it is the most important port in the Gulf of California. Meanwhile, Vallarta is primarily a tourist port. On the one hand, it is devoted to the reception of passengers and cruise ships. On the other hand, it provides infrastructure services to smaller vessels that travel along the large bay near the port. In short, the general objectives presented before the start of the project are:

1. To make sure processes relevant to APIs run more efficiently.

2. To foster a culture of quality within these organizations.

3. To contribute to the modernization of Mexican government agencies.

\subsection{Justification}

In the case of tourist ports, which are responsible for receiving large cruise ships and providing infrastructure services to smaller vessels that offer local tours such as Puerto Vallarta, that are managed by the API, this kind of readjustment (BPR) is truly justified. Indeed, these organizations depend on subtle tasks for fully satisfying their customers who are mostly international tourists. In this context, it is imperative to have high performance parameters. However, in cargo loading and unloading terminals such as the Guaymas API, requirements and commitments to customers with regard to quick and safe handling, at an attractive price are surely as significant. Regardless of the above, in any public or private organization, it is essential to review and improve the way processes run. In short, evidence supports the implementation of this initiative. For example:

1. The importance of business process reengineering in the private sector and the way it is gradually implemented in the public sphere.

2. The relevance of the port sector in international trade and the fact that it is viewed as a strategic area for economic development.

3. The contribution to the improvement of public organizations through the use of state-of-the-art techniques.

4. From a macroeconomic perspective, if the prices of inputs, raw materials, products and services offered by the companies are fixed, the transformation stage, i.e. the way processes are run is what makes companies more competitive and profitable.

\subsection{Participants and Method}

In both ports, following the above defined theoretical framework, human work teams were formed to take part in the initiative according to the following structure: 1 . The general director of the project, represented by the CEO of each API; 2. The Guidance Committee, formed by the managers of each organization; 3. A specialist con-

\footnotetext{
${ }^{4}$ To date, there are 16 federal APIs under the Ministry of Communications and Transport: Altamira, Coatzacoalcos, Ensenada, Dos Bocas, Guaymas, Lázaro Cárdenas, Manzanillo, Mazatlán, Puerto Chiapas, Puerto Vallarta, Progreso, Salina Cruz, Tampico, Topolobampo, Tuxpan and Veracruz. In addition, there are two APIs under the Ministry of Tourism: Cabo San Lucas and Huatulco; four state APIs (managed by the local government) Baja California Sur, Campeche, Quintana Roo and Tabasco; there is also a private API in Acapulco. The results of the reform in ports are clearly favourable and can be found in Torres (2013).
} 
sultant on the matter; and 4. A Business Process Design Team, that included the assistant managers and the heads of the relevant departments in each organization. As previously mentioned, the members of Business Process Design Team are the most important human resources for the project as they are responsible for implementing the revision and the recommendations for improvement at each stage of the process.

In general terms, the method used in the project is aligned with the guidelines that the theory suggests, albeit with certain adjustments required by particular techniques and the context of each organization:

1. Development of an executive agreement between the direction and the management body with regard to the scope of the business process reengineering and the project objectives.

2. Training of human teams for their fulfilment.

3. Identification of the processes vital for the company in order to work on them.

4. Process analysis to generate recommendations for their improvements.

5. Proposals Quantification.

6. Submission of proposals to the direction and the guidance committee for approval.

7. Achievement of agreements with regard to the improvements to implement.

8. Scheduling of actions to execute.

9. Implementation of improvement actions.

\subsection{Results Obtained}

Before reviewing the project results, it is important to note that organizations that seem to be uniform are not monolithic entities. On the contrary, they are dynamic social groups with diverse degrees of complexity. Consequently, the goals, achievements, problems and results of the two APIs participating in the PR initiative will vary and may not be automatically transferred from one organization to another. Indeed, the circumstances, characteristics and missions of both organizations differ radically. In addition to the prevailing organizational culture in each company, the variation in the complexity of the context in which they operate, the resources they receive and the prevailing aptitude and attitude of the participants, is noteworthy. Although, in any company, regardless of their nature, such studies can be addressed by using the same or similar method.

Table 2 shows the achievements in Puerto Vallarta, which is very successful in the processes of boarding and billing. While Table 3 summarizes the results of the API in Guaymas, which include significant improvements in vessel scheduling processes, applications and acquisitions, manoeuvre, billing and accounting.

\section{Discussion: Items to Consider in BPR Projects Development for the Public Sector}

Based on the examples presented here, both from a theoretical and a methodological research perspective and their application, the following criteria should be included in the implementation of these initiatives.

Table 2. BPR results-Puerto Vallarta API.

\begin{tabular}{|c|c|c|c|}
\hline \# & Description & Kind of benefit & Advantaged area \\
\hline 1 & $\begin{array}{l}\text { The time for passenger boarding } \\
\text { process in smaller vessels is } \\
\text { to be reduced by } 47 \% \text {, } \\
\text { from } 14.3 \text { to } 7.6 \text { minutes }\end{array}$ & $\begin{array}{l}\text { *Qualitative: improved service quality } \\
\text { *Economical }\end{array}$ & $\begin{array}{l}\text { Administration } \\
\text { and Finance }\end{array}$ \\
\hline 2 & $\begin{array}{l}\text { The time for the billing process. Collection was } \\
\text { reduced by } 99 \% \text { (from } 15 \text { days to } 4.5 \text { minutes), } \\
\text { equivalent to an improvement of } 10,666 \%\end{array}$ & $\begin{array}{l}\text { *Economical: } \\
\text { *Collection problems are eliminated } \\
\text { *Increased liquidity } \\
\text { *Efficient and reliable process } \\
\text { *Problems that deal with discretion are eliminated } \\
\text { *Responsibilities of the administrative and operational } \\
\text { areas are redefined }\end{array}$ & $\begin{array}{l}\text { Operations and } \\
\text { Administration. } \\
\text { Finance }\end{array}$ \\
\hline 3 & $\begin{array}{l}\text { Implementation of a redistribution Project } \\
\text { of the berthing area for smaller vessels }\end{array}$ & $\begin{array}{l}\text { *Better quality service } \\
\text { *Better promotion for APIVAL } \\
\text { *Organizational and control } \\
\text { *Economical }\end{array}$ & $\begin{array}{l}\text { Operations and } \\
\text { Trading }\end{array}$ \\
\hline
\end{tabular}


Table 3. BRP results-Guaymas API.

\begin{tabular}{|c|c|c|c|}
\hline$\#$ & Description & Kind of benefit & Advantaged area \\
\hline 1 & $\begin{array}{l}\text { Greater participation of the different } \\
\text { levels involved, as they feel being the } \\
\text { "designers" of a better organization }\end{array}$ & Qualitative: improved attitude. & All areas \\
\hline 2 & $\begin{array}{l}\text { The ship programming } \\
\text { board time dropped by } 67 \%\end{array}$ & Economical/Managerial & Operations \\
\hline 3 & $\begin{array}{l}\text { API clients will pay the fees } \\
\text { for service requests at the bank. }\end{array}$ & Better service quality and elimination of risk & All areas \\
\hline 4 & $\begin{array}{l}\text { The use of paper for internal formats } \\
\text { was reduced by two thirds }\end{array}$ & Economical and Qualitative & All areas \\
\hline 5 & $\begin{array}{l}\text { Greater control over the use } \\
\text { of machinery and materials }\end{array}$ & Managerial and Qualitative & Operations \\
\hline 6 & $\begin{array}{l}\text { Writing of the annual budget } \\
\text { on a more realistic basis }\end{array}$ & Managerial and Control & All areas \\
\hline 7 & $\begin{array}{l}\text { The time to process requests and } \\
\text { acquisitions was reduced by } 50 \%\end{array}$ & Economical and Qualitative & All areas \\
\hline 8 & $\begin{array}{l}\text { Planning of a more appropriate number } \\
\text { of jobs on manoeuvres }\end{array}$ & Economical & Operations \\
\hline 9 & $\begin{array}{l}\text { The billing process has improved } \\
\text { by } 50 \% \text { in relation to time }\end{array}$ & Economical and better service & Operations \\
\hline 10 & $\begin{array}{l}\text { Implementation of market research } \\
\text { on potential customers }\end{array}$ & Economical & Trading \\
\hline 11 & $\begin{array}{l}\text { Agree on the preparation of flyers for } \\
\text { all visits to clients or potential clients }\end{array}$ & Qualitative and Managerial & Trading \\
\hline 12 & Preparing monthly work schemes & Qualitative and Managerial & Trading \\
\hline 13 & $\begin{array}{l}\text { To establish who will be responsible for developing } \\
\text { and reporting surveys on the quality of services }\end{array}$ & $\begin{array}{l}\text { Qualitative, Economical } \\
\text { and better service quality }\end{array}$ & Trading and Operations \\
\hline 14 & $\begin{array}{l}\text { Implementation of a standardized process for } \\
\text { the payment to suppliers of goods or services }\end{array}$ & Qualitative and Managerial & $\begin{array}{l}\text { Material Resources } \\
\text { /Administration-Finance }\end{array}$ \\
\hline 15 & $\begin{array}{l}\text { Introduction of standardized process for the } \\
\text { payment to contractors in public works }\end{array}$ & Qualitative and Managerial & $\begin{array}{l}\text { Engineering/Material } \\
\text { Resources/ } \\
\text { Administration-Finance }\end{array}$ \\
\hline 16 & $\begin{array}{l}\text { Paperless handling of information } \\
\text { necessary for public works }\end{array}$ & Economical/Managerial & Engineering \\
\hline 17 & Redefining mission, current and future functions & Qualitative y Managerial & Security and Ecology \\
\hline 18 & $\begin{array}{l}\text { Reduction of time in the accounting process } \\
\text { for income by } 59 \% \text { ( } 51 \text { - } 21 \text { minutes) }\end{array}$ & Economical and Control & Administration-Finance \\
\hline 19 & $\begin{array}{l}\text { Eliminating the use of paper for internal } \\
\text { communication (memos, written notice) }\end{array}$ & Economical and Qualitative & All areas \\
\hline
\end{tabular}

\subsection{BPR Is Not a Totally New Tool but It Must Be Used}

Usually, throughout their professional practice, a significant number of officials and public servants, within the diverse government structures, categorically reject the theory behind business process reengineering because nothing new is suggested. Although the revision and improvement of the relevant processes for companies has been taking place for quite a long time, PR incorporates, as previously noted, certain relatively new elements, designed to markedly improve the way public and private companies carry out processes. For several years, many authors (Paramés, 1978, [11]; Kliksberg, 1989, [12]) have diagnosed the following: BPR should be complemented by the design of flat organizational structures that foster more horizontal management models, problem solving and decision making, and discard the traditional vertical schemes that have made the internal management of public institutions and their interaction with the exterior too rigid and slow.

Repeatedly, groups or actors who reject instruments such as PR and contend there is a lack of novel elements, 
a risk for the government sector goals or that the technique is exclusive to business, perceive PR as a threat to their personal positions. Therefore, despite being able to do so, many organizations have never led a revision regarding the way they are meeting their goals, transforming their inputs to turn them into services, and meeting the expectations of their clients, i.e. the citizens. This behaviour is in fact a real threat to state affairs and the duties of any government. Therefore, it is strongly recommended the implementation of business process reengineering projects as a way to optimize our public organizations, regardless of whether or not the projects are novel.

\subsection{The Initiative about Reengineering Should Come from within the Organization}

The implementation of such a project should originate exclusively from the proposal of the governing body of an organization, which will carry out and implement the project. Undeniably, there is very a common and erroneous habit within the Mexican public administration: senior bodies or officials perceive diverse philosophies, models and management techniques, such as Total Quality Management, Business Process Reengineering or some others identified as part of the New Public Management, as fashionable within the administration. In addition, given the impact these tools have had in the business private sector, they also perceive the implementation of reengineering as an imposition from the private sector to public organizations or departments. When this is the case, the reengineering project is likely to fail. Indeed participants perceive it not as a way to improve the functioning of the organization, but as another obligation, which will turn into a waste of time and resources.

Conversely, if the organization is fully convinced of the scope of reengineering and autonomously decides to undertake this task, the likelihood of success will be significantly higher. The commitment with regard to the perseverance of the various inputs required by reengineering makes the difference.

\subsection{The Sponsor Must Be a Genuine Leader in the Organization and Build a Culture of Satisfaction amongst the Clients}

It is important to reiterate that the director or general manager of the organization must promote and supervise any business process reengineering program. Without that condition, the project will only be a set of good intentions. Furthermore, it is crucial for the manager to be skilful, not only at a structural level, but also at all levels of knowledge and decision-making. The manager needs to be a charismatic leader and a real motivator for the implementation of such projects in the organization. Accordingly, the proposals to improve, which originate from the initiative of business process reengineering, will become a reality. If this criterion is met, the other members of the company's organization will take initiatives for innovation and transformation that will undoubtedly be much less risky.

Reengineering proposes radical changes in the way that strategic processes are run in a company, and those changes must always be designed around citizen-customer's satisfaction. Therefore, it is essential that prior to the implementation of the PR project, the sponsor-leader promotes the development of a course which deals with Total Quality Culture in public administration. This course or workshop will create the conditions for a change in the organization, starting with the members' responsiveness to public service and, among other things, ensure that internal work processes run according to the concept of an internal customer-supplier chain, which ends when it reaches the customer or external client.

As already mentioned, the theory of Total Quality gives reengineering the framework in which reengineering will take place. With the members duly "acculturated", initiatives related to reengineering will be much easier to accept. The objectives will reflect a solid foundation and the results will have a much greater impact.

\subsection{Consider the Dichotomy between Time of Dedication and Incentives}

Theory tells us that participants in BPR projects must allocate all the work time that the initiative requires. This idea is applicable to large private corporations, where labour is more flexible and human capital is sufficient. However, compliance with this rule is virtually impossible in the public sector in our region. Indeed, in the (local) small or municipal organizations, there is a lack of labour and the level of training is generally low. In large organizations, although there is a large amount of human resources, the average level of aptitude is equally low. Thus, the non-attendance of key personnel involved in the PR would be difficult to cover.

Based on our experience, an adequate arrangement in the Mexican government could be that the personnel 
involved in the tasks of BPR would dedicate 2 or 3 hours daily without neglecting their current activities. This proposal addresses two very important concerns: the staffs involved in the project optimize the time dedicated to routine work, and they dedicate the minimum time required for an activity of this importance. Conversely, if the participants had a slight or sporadic dedication towards these jobs, the results would be poor and it would be better not to take the risk of undertaking reengineering efforts.

Moreover, if the staff is forced to participate without any additional stimulus, it will cause them to see the project, based on a cost-benefit calculation, as a burden of work without remuneration of any kind in return ${ }^{5}$. This can cause the personnel to become apathetic or to attend meetings irregularly. Therefore, a strategy could be to offer symbolic incentives such as official credentials for their participation. Monetary incentives could be proportional to their participation and the impact their ideas have on the organization with regard to the initiative. This practice will be complex due to the regulatory rigidity of public management and the difficulty of measuring governance compared to corporate management.

\subsection{Timeline and Regulation}

According to these examples, the results of such initiatives will appear a minimum of three months after the stage of priority ranking and planning. Also, this project should last a minimum of one year. This amount of time is a reasonable period to evaluate every one of the strategic processes for the organization, to make proposals for improvement and to implement most of them. Projects that last only a few months will have a very limited scope of action and their results will not be very relevant. Conversely, BPR initiatives in the public sector that are much longer than one year could fall into a scattering of objectives, commitments, actions and results.

The existing regulations in government agencies are perhaps what have generated the most problems in the development of BPR. Participants repeatedly argued that the proposals for improving processes were not viable because the rules and regulations would prevent their implementation. Even if it is sometimes true that the argument concerning rules and regulations proved valid, most of the time these arguments were based on a misunderstanding of what regulation is intended for, or only on speculation or rumours that attempt to hinder reengineering efforts. Indeed, certain actors faced with the requirements of new activities in terms of commitment and effort, both physical and intellectual, invariably seek to avoid new responsibilities or alter the current state of organization's settings. They refer to the rules and regulations as an excuse not to undertake actions to improve processes ${ }^{6}$.

By no means is the proposal of this research to ignore or violate rules and regulations. On the contrary, it must be assumed as a fact that one of the reasons for the poor performance of Mexican government agencies with regard to politics, social programs, education, public safety and law enforcement, is precisely the poor observance of laws and regulations by the government itself and the society. However, this work is consistent with Barzelay $(1998)^{7}[13]$ and Osborne and Gaebler $(1992)^{8}[16]$ in the sense that it is necessary to understand that the application of the regulations is not the aim of government agencies. On the contrary, their purpose is to satisfy citizens' expectations through delivering effective services and programs. Such initiatives should be conducted keeping this eagerness in mind.

\subsection{BPR Programs Are a Useful Tool but Not a Panacea}

Certain management technologies and theories, such as BPR arise periodically and mostly in the context of large US corporations and academia. In Latin American business, government and even academic fields, it is not surprising to find participants who consider that these management technologies and theories should solve all or at least the most important problems their organizations are facing. This idea is totally false. Processes reengineering programs have certainly proved useful in radically improving the management of both private companies

\footnotetext{
${ }^{5}$ According to Pfeffer (2000) [14], the economic models of organizational behaviour depict individuals as rational, individualist and opportunist. Even if it is difficult to assess the degree of validity of these assumptions, the practice suggests they are valid to some extent.

${ }^{6}$ To this regard, several studies such as Hall (1996) [15] and Arellano et al. (2003) correctly pointed out that organizational change, especially in government agencies, cannot be completely controlled and that adjustments due to different kinds of resistance will definitely be needed.

${ }^{7}$ This prominent academic promoter of the post-bureaucratic paradigm indicates that public organizations should stop following rules and procedures and instead focus on problem solving and continuous process improvement.

${ }^{8}$ As part of a strategy for reinventing government, these authors suggest that the accomplishment of their mission should guide government agencies, not the rules.
} 
and public agencies, through tailoring the way their strategic processes are performed, i.e. the how of the organization. However, given the complexity of the challenges and problems that contemporary organizations face and the fact that these challenges increase and deepen while governments cope with them, it would be naive to think that any models or administrative technologies that come from the exterior could be a solution for all of them. As several scholars (Arellano et al., 2003, [17]) have already mentioned, these tools must be imported when they have proved viable and provided they are adjusted to the reality of the context of Latin America. This idea has guided the present work.

\section{Conclusions}

The observations presented in this study corroborate the importance of business process reengineering projects for improving the management of public agencies and private organizations, which involves an appropriate management of the processes. These processes start with the design of the service and end with its provision. They go through different areas in the organization, thus generating a chain of values that various stakeholders, espeicallly clients or external users appreciate. In this regard, this paper illustrates that the areas of opportunity for a radical improvement of strategic processes are vast. Hence the task must be implemented at certain intervals because the technologies, goals and clients' expectations that are inherent to organizations are changing and becoming more complex in an increasingly globalized world.

This research is an attempt to build a better public administration in Mexico. As previously mentioned, it is part of the efforts for the modernization of management of Mexican ports, which should be up to the requirements of their users, being them, for example, passengers on cruise ships or cargo ships representatives who are increasingly demanding. Finally, tools, such as business process reengineering, adhere to some of the greatest contemporary state's guidelines: management besides being effective in achieving goals is efficient in terms of the rational use of available inputs.

\section{Acknowledgements}

The author is grateful to Germán Alarco Tosoni, the former Coordinator of the Pacífico Norte and Centro APIs for his confidence, as well as Nicole Mercier Cléroux and Claire Merschel Schadler for their support in the translation of this article.

\section{References}

[1] Torres, J.T. (2013) Reforma gerencial en los puertos de México: análisis de las APIS a dieciocho años de su creación. In: González, F. and Ojeda, J.N., Eds., Los puertos de España y México, NETBIBLO, Instituto Universitario de Estudios Marítimos, La Coruña, 93-313.

[2] Hammer, M. and Champy, J. (1993) Reengineering the Corporation: A Manifesto for Business Revolution. Harper Collins, New York.

[3] Manganelli, R.L. and Klein, M.M. (1995) Cómo hacer Reingeniería. Norma, Bogotá.

[4] Institute of Industrial Engineers (IIE) (1995) Más allá de la Reingeniería. CECSA, México, D.F.

[5] Harbour, J.L. (1995) Manual de Trabajo de Reingeniería de Procesos. Panorama, México, D.F.

[6] McDonald, J. (1996) Cómo entender Reingeniería de Procesos. Panorama, México, D.F.

[7] Caudle, S.L. (1994) Reengineering Strategies and Issues. Public Productivity and Management Review, 18, $149-162$. http://dx.doi.org/10.2307/3380644

[8] Centro Latinoamericano de Administración para el Desarrollo (CLAD) (1998) Declaración de Lisboa. http://www.clad.org/documentos/declaraciones/declaracion-de-lisboa/?searchterm=declaración de lisboa

[9] Centro Latinoamericano de Administración para el Desarrollo (CLAD) (2002) Declaración de Santo Domingo. http://www.clad.org/documentos/declaraciones/declaracion-de-santo-domingo/?searchterm=declaración de santo domingo

[10] Buscador General del SIARE del CLAD (Información Bibliográfica sobre Estado, Administración y Sociedad). http://siare.clad.org/siare/bgeneral/php/inicio.php

[11] Paramés, C. (1978) Introducción al Management. ENAP, Madrid.

[12] Kliksberg, B. (1989) Gerencia pública en tiempos de incertidumbre. INAP, Madrid.

[13] Barzelay, M. (1998) Atravesando la burocracia. Una nueva perspectiva de la administración pública. Fondo de Cultura 
Económica, Ciudad de México.

[14] Pfeffer, J. (2000) Nuevos rumbos en la Teoría de la Organización. Oxford University Press, México, D.F.

[15] Hall, R. (1996) Organizaciones: Estructuras, Procesos y Resultados. Prentice Hall, Naucalpan, estado de México.

[16] Osborne, D. and Gaebler, T. (1992) Reinventing Government. Addison Wesley, Boston.

[17] Arellano, D., et al. (2003) Reformando al gobierno. Una visión organizacional del cambio gubernamental. CIDE, México, D.F. 